Supplement of Nat. Hazards Earth Syst. Sci., 18, 3283-3296, 2018

https://doi.org/10.5194/nhess-18-3283-2018-supplement

(c) Author(s) 2018. This work is distributed under

the Creative Commons Attribution 4.0 License.

(c) (1)

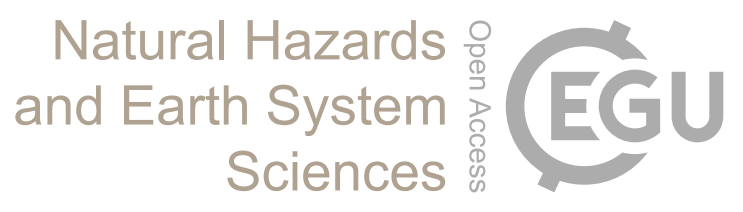

Supplement of

\title{
Potential impact of climate change and extreme events on slope land haz- ard - a case study of Xindian watershed in Taiwan
}

Shih-Chao Wei et al.

Correspondence to: Hsin-Chi Li (hsinchi@ncdr.nat.gov.tw)

The copyright of individual parts of the supplement might differ from the CC BY 4.0 License. 


\section{Supplement of Classified levels of average soil depth on different slopes}

Table S1 Classified levels of average soil depth on different slopes; the soil depths and slopes were surveyed from the historical landslide area with the DEM before and after landslide (after Chen et al., 2010)

\begin{tabular}{|c|c|c|c|c|c|}
\hline $\begin{array}{c}\text { Slope } \\
\text { degree })\end{array}$ & $\begin{array}{c}\text { Shimen } \\
\text { watershed } \\
\text { northern Taiwan } \\
(\mathrm{m})\end{array}$ & $\begin{array}{c}\text { Dajia } \\
\text { watershed } \\
\text { middle Taiwan } \\
(\mathrm{m})\end{array}$ & $\begin{array}{c}\text { Landslides triggered by } \\
\text { Typhoon Aere } \\
\text { in Shimen watershed northern } \\
\text { Taiwan }(\mathrm{m})\end{array}$ & $\begin{array}{c}\text { Average } \\
(\mathrm{m})\end{array}$ & $\begin{array}{c}\text { Classified } \\
\text { Levels } \\
\text { in Figure } 8 \\
(\mathrm{~m})\end{array}$ \\
\hline$<20$ & 1.41 & 3.04 & 0.32 & 1.59 & 1.5 \\
\hline $20 \sim 30$ & 3.13 & 4.19 & 2.82 & 3.38 & 3.5 \\
\hline $30 \sim 40$ & 3.51 & 5.33 & 4.27 & 4.37 & 4.5 \\
\hline $40 \sim 50$ & 2.17 & 3.49 & 1.98 & 2.55 & 2.5 \\
\hline$>50$ & 1.82 & 1.33 & 0.20 & 1.12 & 1.0 \\
\hline
\end{tabular}

Chen, S. C., Wu, C. H., and Wang, Y. P.: The Discussion of the Characteristic of Landslides Caused by Rainfall or Earthquake, Journal of Chinese Soil and Water Conservation, 41, 94-112, 2010. 